\title{
Research on Urban Low Income Housing Policy Delivery in Tamale, Ghana
}

\author{
Eunice Yorgri ${ }^{1}$, Prof. Leng Hong ${ }^{2}$, Prof. Cheng Wen ${ }^{3}$, Jamani Patience ${ }^{4}$
}

\begin{abstract}
Housing among other amenities is a basic right entitled to every individual in any human enclave and proper and decent housing is of great value in all spheres of life because it enhances safety, security and honour. Generally, access to decent housing is a global problem and a tremendous magnitude both in quantity and quality. Ghana has a housing deficit of 1.7 million which has become a major challenge to successive governments. Rapid urbanization among other factors have been blamed for the acute housing shortages which have resulted in escalating housing prices and rent in most urban areas, especially areas where there are perceived job opportunities resulting in shanty towns and slums development. This has made the provision of affordable housing one of the daunting challenges in the socio-economic development of Ghana. Despite efforts made by successive governments in addressing housing problems, housing deficits still paddles on. This study employed quantitative and qualitative methods of data collection from both primary and secondary sources. It does so by surveying literature from policy documents, reports, journals, books and through questionnaires and interviews. The study revealed that housing policies have failed to achieve results due to gaps in the implementation of such policies. There are insufficient affordable houses in Tamale. We recommend that housing policy document should be utilized, decentralized and also periodically evaluated against stated objectives to assess progress. Government should also collaborate with the private sector in the form of Public Private Partnerships to provide housing affordable for all income groups since this has proven to have produced better results in other countries.
\end{abstract}

Keywords - affordable housing, housing deficit, housing policy, public-private partnership.

\section{INTRODUCTION}

Housing challenges arise from mismatches between policy instruments and objectives, as well as from conflicts between various housing and non-housing objectives and also arising from conflicts between limited and competing resources and objectives. More than one billion of the world's total urban population according to UN-Habitat lives in inadequate housing, mostly in slums and squatter settlements of the developing world (UN-Habitat, 2011). Currently Ghana is facing severe housing problem with housing deficit being in excess of 1.7 million units. This is because rapid urbanization and urban growth coupled with population increase has resulted in escalating the prices of houses in most urban areas, especially areas where there are perceived job opportunities (Turner et al.). This has made the provision of affordable

Harbin Institute of Technology, School of Architecture, Department of Urban and Rural Planning, Harbin, China. housing one of the daunting challenges in the socio-economic development of Ghana. Housing shortage can be traced back as far as the 1970 as shown below.

TABLE I: HoUSING DEMAND IN GHANA: 1970 TO 2010

\begin{tabular}{cccc}
\hline \multirow{2}{*}{ Year } & Housing & Housing Supply & Housing \\
\cline { 2 - 4 } & Demand & $\begin{array}{c}\text { (Dwelling } \\
\text { Units) }\end{array}$ & Deficit \\
\hline 1970 & $1,678,296$ & 941,639 & 736,657 \\
1984 & $2,410,096$ & $1,226,360$ & $1,184,636$ \\
2000 & $3,708,250$ & $2,181,975$ & $1,526,275$ \\
2010 & $7,417,607$ & $5,817,607$ & $1,600,000$ \\
\hline
\end{tabular}

Source: authors' compilation from GSS 2005, UN HABITAT and 2010 Population and Housing Census

Since independence successive governments have been striving to cater for the housing needs of the people. However, the gap between intentions and achievements is wide both in the rural and urban settings. Different political ideologies of various political parties over the years account for the change in policy directions in terms of housing provision especially for the urban poor or low-income households. Despite the concerted efforts successive governments in Ghana have made to bridging the gap in housing supply and demand through various policies and programs, before and after independence, studies however clearly indicates the inability of interventions and housing delivery systems of all kinds to satisfy these basic conditions, particularly at affordable levels for low-income households (Ansah S. K., 2014).

Nevertheless issues of how these policies are being formulated, what goes into the implementation process and reasons why these policies have not been able to realize their policy goals are questions that need answers. In addition, policies formulated by various countries usually have specific goals and objectives. However, most of these policies end up satisfying some group of people in the society while marginalizing others especially the urban poor. Several countries have adopted a wide range of programmes and formulated policies and strategies to ensure effective delivery of decent and affordable housing. Some countries such as Sweden, Denmark, Singapore and the Netherlands have adopted a more universal approach wherein decent and affordable housing is provided to target the whole population.

Ghana has witnessed numerous shelter policy changes but the housing situation in the country is still abysmal. The affordable housing projects which were meant to house the urban poor were abandoned by successive governments for unknown reasons. This research therefore seeks to review previous shelter policies in Ghana with the aim of examining 
the policy formulation and implementation process, and determine the effectiveness of these housing policies in providing affordable housing for low income groups. All these gaps in the policy formulation process and its implementation towards affordable housing provision for low income housing has triggered the researcher to carry out a critical evaluation study on housing policies and programs using Tamale as a case study area.

\section{METHODOLOGY}

Methodology deals with the procedure of the research process, data collection, analysis and presentation in order to achieve research objectives. Therefore, random sampling was used as the appropriate sampling procedure due to the nature of information needed and distribution of respondents in the area of study. The target population in this research consisted of residents in some selected neighborhood and government agencies involved in housing provision. The research approach consisted of data obtained from both primary and secondary data sources. Primary data were collected from the field by the use of structured questionnaires which were administered to randomly selected households in the study area. A total of 131 questionnaires were administered while field observation and interviews were other techniques used for collecting data from the housing ministry. Desk top study also known as secondary data was obtained from available documents including annual reports, media publications, academic research journals, articles, books and relevant policy documents. Analyses of data were done using Microsoft Excel and presented in table forms whilst results were presented in the form of pie and bar charts as well as narratives.

\section{RESULTS AND DISCUSSIONS}

\subsection{Urban Housing Delivery in Ghana}

Housing is a basic necessity of life of every nation and the quality of housing used by any household establishes a fundamental basis for assessing the standard of living of the household and to some extent, the nation as a whole. The UN Habitat in their report on housing in Ghana and poverty reduction confirms that rapid urbanization in the cities of Ghana and Africa as a whole has affected the institutional capacity to deliver not only affordable housing but durable and high quality shelter that meets the health needs of urban dwellers. About $47.2 \%$ of dwelling units are owner occupied while 31.17 lived in rented premises. The 2010 population and housing census indicate that the total stock of houses in the country is 3,392745 with a deficit of over 2 million units. Results of the census also indicated that the average household size in Ghana was 4.4 in the 2010 census as compared to 5.1 persons in 2000, with about 1.6 households per house in 2010 and 1.7 households per house in 2000.This number of households compared to that of the population, clearly indicates that most houses are severely overcrowded. Housing units are classified as Separate house, Semi detached, Flat/Apartment, Compound house, Huts/buildings (same compound), Huts/buildings (different compounds), Tent,
Improvised home (kiosk, container), Living quarters attached to office or shop and Uncompleted building.

\subsection{Urban Housing Situation in Tamale, Ghana}

The housing situation in Ghana is rather a worsening one and the urban areas are the most affected mainly because of increasing urbanization and people migrating from the rural areas to the urban centers in search of greener pastures and Tamale is one of such areas since it doubles as the regional capital of the Northern Region. It is also the second largest in terms of area size in Ghana and the third largest settlement and fastest growing city in West Africa. Due to its central location, it serves as a hub for all administrative and commercial activities in Northern region. Currently in Tamale a flat or an apartment is being sold at $\mathrm{GH} \phi 140,000$ which is equivalent to $\$ 32,992$ based on current exchange rates $(\mathrm{GH} \not 1.00 \sim \$ 3.8)$. Uncompleted houses are also sold between $\mathrm{GH} \phi 75,000$ and $\mathrm{GH} \not 120,000$. What makes the situation even worse is the fact that buying these houses requires an upfront payment of the total cost. Due to the low levels of incomes in Tamale coupled with lack of access to housing finance and mortgage facilities, households indulge in incremental housing which may take up to five years before completion. Unfortunately, the incremental process is not only very expensive, but it wastes a lot of resources often, house units become aesthetically and functionally outdated after completion.

According to the United Nations Global Report on Human settlements, the cost of a complete dwelling could be 2.5 to 6 times the average annual salary of a worker. This however reflects in the findings of the income distribution of the respondents. On household incomes of respondents, majorit y of the respondents received low to average incomes. (28\%) of the respondents receive up to GHS700.00 which is fairly inadequate looking at the current economic conditions found in the country and the study area. With (17\%), (11\%), (9\%) receiving up to GHS 300.00, GHS400.00 and GHS 500.00 respectively. However, only (9\%) of the respondents receive the highest incomes that are up to GHS 800.00. Thus in general, the per capita income of the respondents is low. This gives an indication of the types of dwelling unit in Tamale and how many can really afford such accommodation given their level of income. What can be deduced from this is that majority of the respondents are public servants whose incomes are generally low considering the current state of the country's economy. These are income categories that are not eligible for any mortgage facility and as such would have to access housing with these little incomes.

An investigation into their housing ownership tenure revealed that, most of them representing $(71 \%)$ had rented the houses they were occupying while (29\%) were owner occupiers. This however buttresses what Rakodi observed, that greater attention has been paid to rentals in recent years and the significance of rental housing in providing shelter to lowincome households in cities of developing countries had been underscored. Findings also revealed that majority of the respondents who owned houses actually acquired them through the State Housing Company and SSNIT. Those who were renting in private rented houses accounted for $(55.7 \%)$ while $(29.8 \%)$ lived in government quarters and bungalows. The 
survey also sought to investigate into the type of housing the respondents occupied and results indicates that $(48.1 \%)$ of the sampled population live in compound houses, while $(29.8 \%)$ also live in apartments with $(16.8 \%)$ living in bungalows and $(5.3 \%)$ living in semi-detached houses.

TABLE II HOUSING STATUS OF RESPONDENTS FROM SURVEY

\begin{tabular}{ccc}
\hline Housing status & Frequency & Percentage \\
\hline Owner occupier & 38 & $29 \%$ \\
Renting & 93 & $71 \%$ \\
Total & 131 & $100 \%$ \\
\hline
\end{tabular}

Findings from the tenure dynamics indicate that majority of the respondents live in private rented houses most especially in compound houses. This could be as a result of low rent charged for accommodation which residents are able to afford considering their low income levels.

\subsection{Low Income Housing Policy Delivery in Tamale}

The National Housing Policy and Action Plan (1987-1990) was the first direct attempt in the post-colonial era to institute a coherent framework to specifically guide the activities of all the state and non-state actors in the housing sector. Comprehensive National Shelter Strategy, draft (1991-1992) was also prepared in collaboration with UN-Habitat (UNCHS) but was never implemented partly because the impetus for a housing policy had weakened substantially.

Housing provision in Ghana has also experienced fragmented effort from individuals, private developers and successive governments. Several affordable housing schemes were implemented before independence (colonial Era), after independence (post independence), Military era and even present. Between 1992 and 2013, the state's involvement in housing delivery has been minimal. No considerable additions had been made to public housing until 2001, when the NPP government sought to reduce the housing crisis through the initiation of about 20,000 affordable housing units. Three thousand acres of land were acquired at Accra, Brekuso, Kuntanase, Asokore Mampong, Wa, Tamale and Amanfrom for the construction of affordable housing units. Sadly, not a single dwelling unit remains completed up to date and the most of the completed ones have been taken over by squatters. The draft National Housing Policy (2009) was drawn at that time but never translated into a comprehensive working document. In line with the new draft national housing policy, 100,000 low cost houses were to be built at a unit price of GHC9000. The draft housing policy document of 2009 was finally implemented in 2015 after long deliberations. The policy sought to address the issues in urban housing development in Ghana. The housing policy was aimed at providing adequate, decent and affordable housing that is accessible to satisfy the needs of all Ghanaians. Government housing policy interventions has done little in meeting the housing requirements of low income groups.

High cost of building materials (16\% of Respondents) resulting in the overall high cost of construction is yet another challenge in the housing industry. According to the survey, respondents also mentioned lack of housing finance $(15.3 \%)$ as a factor militating against their access to decent and affordable housing. Its implication is that households would have to resort to their meager household incomes in order to be able to construct a place of abode. Housing finance should be extended to more people especially the poor through government led legal, regulatory, institutional and administrative measures and reforms. This can be done by reducing interest rates, easy collateral requirements and flexible terms of payments.

\subsection{Housing Affordability in Tamale}

A research by Bank of Ghana indicates that only a few banks offer mortgage loans and usually to high net worth patrons who are more likely to pay back with interest than low and middle income earners. In a similar research by Quayson indicates that only $8 \%$ of Ghanaians can afford to purchase a property without mortgage and yet only $15 \%$ of the population can access mortgages. The housing affordability problem has been intensified by the huge advance payments more often than not (between 1 and 3 years) that landlords demand from tenants. This constraint of having to make lumpy one year payment in advance has produced a barrier to accessing decent housing in spite of a Rent control Act (Act 220) which clearly states that rent advance should not exceed 6 months. Majority of the respondents fell within the range of GHS 300 and GHS 600. Fig. 1 shows the percentage distribution of average net monthly incomes of respondents recorded in the survey in Tamale.

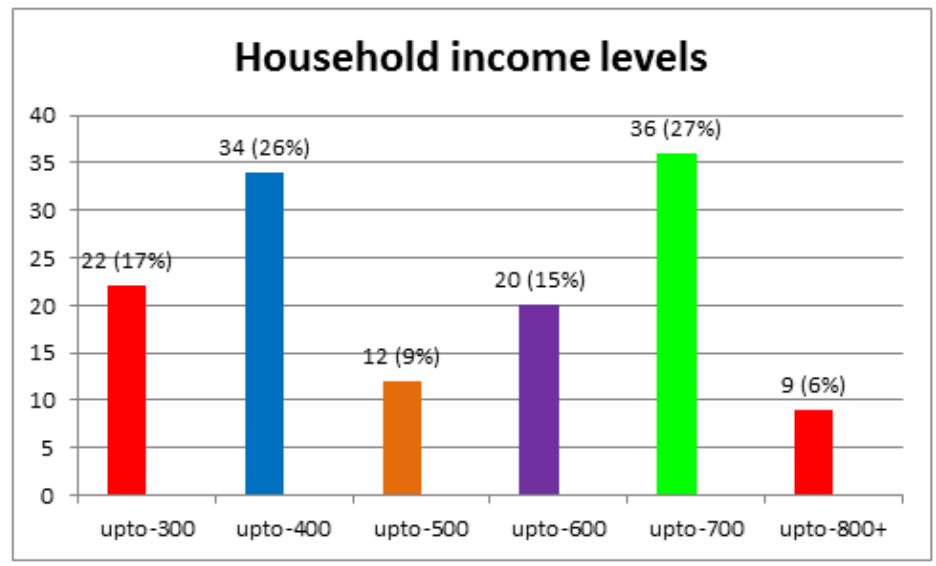

Fig. 1 Household income distribution of respondents in Tamale

An interview with a key informant from the MWRWH indicates that, institutional arrangements within the housing sector remains fragmented, inconsistent with existing regulations and inadequately funded. It is characterized by lack of clear cut roles and responsibilities, definition and appropriately delineated lines of accountability. There have been weak links between national housing policies and the regional and local level where housing development actually takes place. It was also discovered that governments engage directly in housing development and allocation with little recourse to local government planning and needs. Furthermore, there exists a disconnection between national housing policy and housing supply. According an official of the ministry, the State Housing Company has constructed some flats around the Tamale Airport which costs GHS140,000 but due to the cost, residents complain the apartments are not 
affordable. The Tamale affordable housing project is yet another effort the state begun to supply mass affordable houses to low income households in Tamale. This project was started in 2014 aimed at constructing 200 affordable housing units in Lahagu, Tamale and is funded by Homeless International Organization based in the United Kingdom in partnership with the government, chiefs, Water and Sanitation Agency and Tamale Co-operative Credit Union. Construction however stalled while the project was only $65 \%$ completed due to lack of funds by partners. Results from the survey indicates that ( $22 \%)$ of respondents ranked the enabling of the private sector to deliver affordable housing highest in measures to improve affordable and decent housing. Due to the low income level of the people, compound houses are the common type of dwelling affordable to residents with $(48.1 \%)$ of respondents living in them. Findings revealed that $(55.7 \%)$ of respondents live in rented houses with $(44.3 \%)$ being owner occupiers. This implies that the role of the citizens themselves in affordable housing provision cannot be over looked.

Corruption in the allocation of public housing units also militated against the success of policies as houses which were intended for low income households unfortunately ended up in the hands of the high class and the rich in society with the target beneficiaries ending up as tenants. Another issue is the abrogation or non-continuity of policies and programmes by previous governments. It was discovered that even in the absence of a comprehensive housing policy, governments still embarked on housing projects with the aim of reducing the deficits and a new housing policy was implemented in 2015 with the goal of providing adequate decent and affordable housing accessible to all Ghanaians.

Based on the goals and objectives of housing policies in the country, respondents were asked to give their opinions if indeed policies had made an impact especially in the provision of decent and affordable housing. It was discovered that $(61.1 \%)$ of respondents of individual households have knowledge of housing policies though they did not know what actually entails in it. While (38.9\%) of the respondents said they were not aware of any housing policy. This could be due to the fact that majority of the respondents have some form of formal education and are abreast with issues concerning shelter. Governments should therefore put measures to sensitize the public on housing policies.

With regards to the impact of housing policies on affordable housing provision, (70.2\%) of the respondents were of the view that housing policies have failed to deliver housing to residents while (22.9\%) agree that housing policies have lived up to expectations with another (6.9\%) with no response. When asked to give reasons for their views, some of the respondents complained about the rent cap which has been in existence since independence but lacked enforcement leaving tenants in the hands of land lords who exploit them by requesting for more than one year advance rent payment. Further analyses about their impressions about suppliers of housing in Tamale were that, the cost of rent range between GHS 20.00 and GHS 450 depending on the location, facilities and type of dwelling. And they were usually faced with unrealistic payment plans by landlords and some corrupt ones who tend to exploit tenants. This could be a pressing issue since most of the respondents are tenants. Others were of the view that, policy enforcements on renting dynamics in the country never existed and if even there were such policies, they had no knowledge about them. Some respondents acknowledged the efforts government was making in the area of affordable housing but expressed worry at how projects were abandoned. Some of the housing projects are usually located very far from town without infrastructural developments. An example was given about the affordable housing project on the Salaga road which has been abandoned for no apparent reason.

\section{RECOMMENDATION AND CONCLUSION}

\subsection{Recommendation}

Based on the above findings we recommend that the new housing policy which has just been implemented should be periodically reviewed as against the objectives so as to determine the level of success. Also, consistency and continuity of housing policies and programmes in Tamale is a prerequisite for sustainable housing provision and development. This should strictly be adhered to irrespective of differences in political ideologies. Government should incentivize the private estate developers through attractive incentives such as tax holidays and rebates and easy access to credit facilities in order to be lured into affordable housing provision in Tamale. A backing policy should be implemented to support housing loans for the urban poor. Public private partnerships are noted to have been effective in housing and infrastructure delivery. Governments should therefore partner with the private sector to provide housing especially for low income groups.

\subsection{Conclusion}

A critical examination of the housing stock and characteristics in Ghana and Tamale indicate that residents live in overcrowded rooms and houses in deplorable conditions which lack basic amenities such as toilet and drainage facilities. This could lead to the spread of communicable diseases. Governments should increase the construction of more affordable housing units for low income households. Prudent measures should be instituted to ensure that work continues in the Tamale Affordable housing project which has been stalled due to lack of funds from the partners involved.

It was also discovered in the study that due to low incomes, residents have resorted to renting of rooms mostly in compound houses. Government should invest in rental housing especially in urban areas. These could be in the form of multihabited dwellings or apartments constructed in areas with adequate infrastructural developments such as roads, potable water, security etc. Challenges low income households face in accessing housing in Tamale include high rent and demand for advance rent payments, high cost of land, acquisition of building permits, lack of finance amongst others. This makes housing unaffordable and could lead to the proliferation of slums. Suggested solutions by respondents for an effective affordable housing provision includes the provision of 
affordable housing units for all income levels, increasing private sector participation, encouraging self-help housing approaches, providing access to housing finance, encourage the use of local building materials, ensure proper funding and implementation of housing projects and strengthening institutional frameworks for effective housing delivery.

\section{BIBLIOGRAPHY}

[1] A.G. Tipple and D Korboe "Housing Policy in Ghana. Towards a Supply Oriented Future" Habitat International (1998) 22 (3) 1998 pp245-257.

[2] Adjei K. O. Fobiri G. Owiredu, G. K "Policies and Barriers in the provision of affordable housing in Ghana. www.ajaronline.com. 2015, Vol. 1, No. 1.

[3] Andrew P. B, Bridget K, Johannes G. P. "Housing Affordability and Planning in Australia. The Challenge of Policy Under Neoliberalism"

[4] Ansah S. K. "Housing deficit and delivery in Ghana: intervention by various Governments". International Journal of Development and Sustainability. Vol. 3 No. 5 (2014): pages 978-988

[5] Bank of Ghana "The Housing Industry in Ghana, Prospects and Challenges: Bank of Ghana Policy Briefing paper-Accra: Bank of Ghana (2007) The Housing Market in Ghana. (2007)"

[6] Biitir, S. B. "Provision of Affordable Housing for Low Income Groups in Tamale Metropolitan area through Self-Help Housing Approach" (2009). Un-Published Master Thesis, Department of Land Economy, Kwame Nkrumah University of Science \& Technology

[7] Boamah N.A. "Housing Policy in Ghana: The Feasible Paths" GJDS, Vol 11, No. 1 May (2014)

[8] Boamah, N. A. "Housing Finance in Ghana: World Community Mortgage Co-operatives Provide a Panacea?" Ghana Journal of Development Studies, vol.7, No. 1. 2010. https://doi.org/10.4314/gjds.v7i1.61399

[1] Ghana National Housing Policy Document (2015)

[2] Ghana Statistical Service (GSS) 2012

[3] Ghana Statistical Service " 2000 Population and Housing Census, Northern Regional Analysis" (2005) Accra:GSS

[4] Ghana Statistical Service "Ghana Living Standards Survey" Report of the Fifth Round (GLSS 5) (2008)

[9] Ghana Statistical Service, "2010 Population and Housing Census; Summary Report of Final Results (2010

[10] Irene Appeaning Addo, "Urban Low-Income Housing Development in Ghana: Politics, Policy and Challenges" (2014) Regional Institute for Population Studies (RIPS),

[11] Nicholas, A. B "Housing affordability in Ghana: A focus on Kumasi and Tamale" Ethiopian Journal of Environmental Studies and Management Vol. 3 No. 32010

[12] Quayson A. " Ghana Primary Mortgage Market Initiative" Housing Finance International (2007

[13] Turner, M. A. \& Kingsley, G. T. Federal "Programs for Addressing Low-Income: A Policy Primer" The Urban Institute. 2008

[14] UN-HABITAT "Housing and Urban Development in Ghana :With special reference to low-income" (2004).

[15] UN-HABITAT, " Affordable Land and Housing in Africa” (2011).

[16] UN-Habitat, Ghana Housing Profile 2011: Global Report on Human Settlements(2011)

[17] UN-Habitat, State of the World's Cities 2006/2007, The Millennium Development Goals and Urban Sustainability, (2006), London, U.K.

[18] Von Hoffman A. "History lessons for today's housing policy: the political processes of making low-income housing policy. 2012. 